\title{
János Bodoróczki
}

\section{Small NATO Member and Partner Countries in Special Operations Component Command - Opportunities for Logistic Support}

\section{Kis NATO tag- és partnerországok a különleges múveleti komponens parancsnokságban - logisztikai lehetőségek}

This paper fills a gap in the line of articles on this subject. No publication can be found that analyses the logistic possibilities of small states concerning Special Operations Component Command. The topic is timely, its problem solving is innovative. The analysis is unique and outstanding. Its added value, therefore, is significant. This article might be a fundamental reading of military sciences concerning SOF peculiar logistic support and Special Operations Component Command's logistics. The first chapters of the article summarise the core activities of the Special Operations Forces, and the essence of the Special Operations Component Command. The rest of the article presents a short overview of the requirements of the Special Operations Component Command, concerning logistic support. The author analyses the Special Operations Forces peculiar logistic support, and the fundamentals of the Special Operations Component Command logistic support. Finally, the article presents a logistic support concept for small nations, concerning the Special Operations Component Command.

Keywords: Special Operations Component Command, Special Operations Forces, logistics, requirement, concept, fundamentals, small state, small country, SOF, SOCC 
A cikk hiánypótló munka. Eddig nem létezett olyan publikáció, amely a kis államok lehetőségeit elemezi a különleges müveleti komponens parancsnokság feladatrendszerét figyelembe véve. A téma időszerủ a problémamegoldás innovatív. Az elemzés egyedi és kiemelkedő. A hozzáadott érték ezáltal jelentős. A cikk a különlegesművelet-specifikus logisztikai támogatási és a különleges müveleti komponens parancsnokság logisztikai támogatását elemző alappillér lehet. Az első fejezetek összegezik a különleges műveleti erők és a különleges műveleti komponens parancsnoksági alaprendeltetés szerinti feladatrendszerét. A cikk második része rövid áttekintést nyújt a különleges müveleti komponens parancsnokság követelményrendszeréröl a logisztikai támogatással kapcsolatban. A szerző elemezi a különlegesművelet-specifikus logisztikai támogatást és a különleges müveleti komponens parancsnokság logisztikai támogató rendszerének alapjait. Összegzésként a cikk egyfajta logisztikai támogatási elgondolást javasol azoknak az államoknak, amelyek a jövőben egy különleges müveleti komponens parancsnokság alárendeltségében kívánják alkalmazni különleges eröik egy részét.

Kulcsszavak: különleges müveleti komponens parancsnokság, követelmény, különleges müvelet, logisztika, alap, koncepció, kis állam, kis ország

\section{Introduction}

The creation of the Special Operations Component Command (SOCC) has played a significant role in connection with the NATO Response Forces (NRF). Due to the challenges of the $21^{\text {st }}$ century, special operations forces seem to be the tool for the future. The vast majority of the NATO, and partner small countries had focused on developing Special Operations Forces (SOF) capabilities to contribute to NATO. SOF involvement in NATO operations is particularly important.

This includes assisting with SOF force generation, integration into strategic and operational planning, and SOF-specific intelligence analysis. There is a SOCC element responsible for command and control of SOF within the NRF. This element is provided on a rotational basis by a handful of countries, which possess the requisite SOF capacity and capability [1].

Since SOF is expected to take the lead in future NATO operations, this research focuses on the way how the small countries' SOF can contribute to the SOCC.

\section{SOF Core Activities}

The development of SOF has played a significant role in the small NATO member, and partner countries [2: 73]. I am convinced that this is a new opportunity for interoperability between NATO countries and partners. Though since its formation, SOF has been engaged in combat operations, it is expected to be the key tool for future NATO operations. In past NATO led operations, SOF played a pivotal role. Small countries' SOF had contributed greatly in those operations. This chapter focuses 
on determining the core activity of SOF. The primary question is: What does SOF core activity mean?

According to Admiral Eric T. Olson" "Special Operations Forces are contributing globally well beyond what their percentage of the total force numbers would indicate. Every day they are fighting our enemies, training and mentoring our partners, and bringing value to tens of thousands of villagers who are still deciding their allegiances" [3: $\|-1]$.

These words perfectly summarise the essence of Special Operations (SO). Core activities are determined by JP 3-05, as follows:

- Direct action (DA)

- Special reconnaissance (SR)

- Countering weapons of mass destruction (CWMD)

- Counterterrorism (CT)

- Unconventional warfare (UW)

- Foreign internal defence (FID)

- Security force assistance (SFA)

- Hostage rescue and recovery Counterinsurgency

- Foreign humanitarian assistance

- Military information support operations (MISO)

- Civil affairs operations (CAO) [4: II-3]

The core activities of SOF are based on the type of conflict, the environment, and the scope of the operation. This kind of mission may include more than one core activity. The execution of one core activity may have operational or strategic impact on other core activities being planned or executed. While executing a major operation or campaign, the followings are some examples of the supporting aspects of some special operations activities that may be conducted:

- SR and DA missions

- Hostage rescue and recovery supports personnel (PR) for the joint force

- FID and SFA may support training, advising, and equipping host nation security forces as an element of a counterinsurgency (COIN) operation

- MISO may be conducted to gain/erode support of a foreign population

- CAO are conducted across the range of military operations to enhance the operational environment by identifying and mitigating the underlying causes of instability within civil society or applying functional specialty skills normally the responsibility of civil government to foster stability

- CT and CWMD may be mutually supportive because of the potential nexus of certain terrorists and the proliferation of weapons of mass destruction (WMD)

- During a COIN operation, FID, DA, SR, CT, MISO, and CAO are likely to be conducted [4: II-3, II-4]

Admiral Eric T. Olson, Commander of the United States Special Operations Command. 


\section{NATO SOF Requirements}

Every nation that will contribute a SOF element to NATO must determine which national special organisation best suits its national requirements for SOF. Capabilities of designated units must meet NATO's requirement. This requirement has been identified by the NATO Special Operations Headquarters in the NATO SOF Study. These requirements are the following:

- Conduct J1-J6 staff functions

- Plan, coordinate and direct special operations separately or as part of a larger force

- Command subordinate SOTUs, CS units and CSS units

- Maintain OPSEC, to include restrictive OPSEC procedures involving sensitive or compartmented SOF operations

- Manage force protection for the SOCCE headquarters, as required

- Deploy within established deployment timelines with all classes of supply to sustain itself for 10 days

- Sustain itself once deployed with its organic CSS capability via host nation support (HNS) agreements and/or tailored national support arrangements

- Establish liaison element on the appropriate level to provide advice, coordination, and staff assistance on the employment of SOF to superior SOF and/ or conventional headquarters

- Provide augmentation to superior SOF and/or conventional headquarters

- Perform all-source intelligence analysis and fusion

- Disseminate tactical intelligence

- Incorporate intelligence products into mission planning

- Conduct surveillance of a target using UAVs

- Conduct chemical, biological, radiological, nuclear (CBRN) reconnaissance using accredited metering systems

- Conduct tactical signal intelligence (SIGINT) gathering operations

- Provide SOF teams with an embedded language capability to train and advise and/or employ with national military or paramilitary forces

- Provide organic powered vehicle mobility [2: 59]

The minimum NATO compatible SOF unit is Special Operation Task Unit (SOTU). This is the core element of the NATO Special Operations Component Command (SOCC). Consequently, there cannot be difference among the nucleus of SOF, their proceeding, methodology and support.

\section{SOCC Requirement}

The first and second chapters summarise the essence of SOF core activities, and NATO SOF requirements. This chapter explains a notional SOCC concept in order to preamble the SOF/SOCC unique logistic support. 
SOCC is a multinational or national joint component command (CC). It is formed around a framework nation (FN). SOCC are non-standing HQ in the NATO Force Structure. This is tailored for each operation according to the number of special operations task groups (SOTGs). The FN forms the nucleus of the SOCC (commander, key staff personnel, C2, information systems, and basic life support functions). The FN will also be expected to coordinate the combat service support functions for the component. FN is expected to provide at least one SOTG and a tactical airlift capability. Other NATO nations can contribute personnel to the SOCC [5: 13-14].

The next figure presents a notional SOCC organisation.

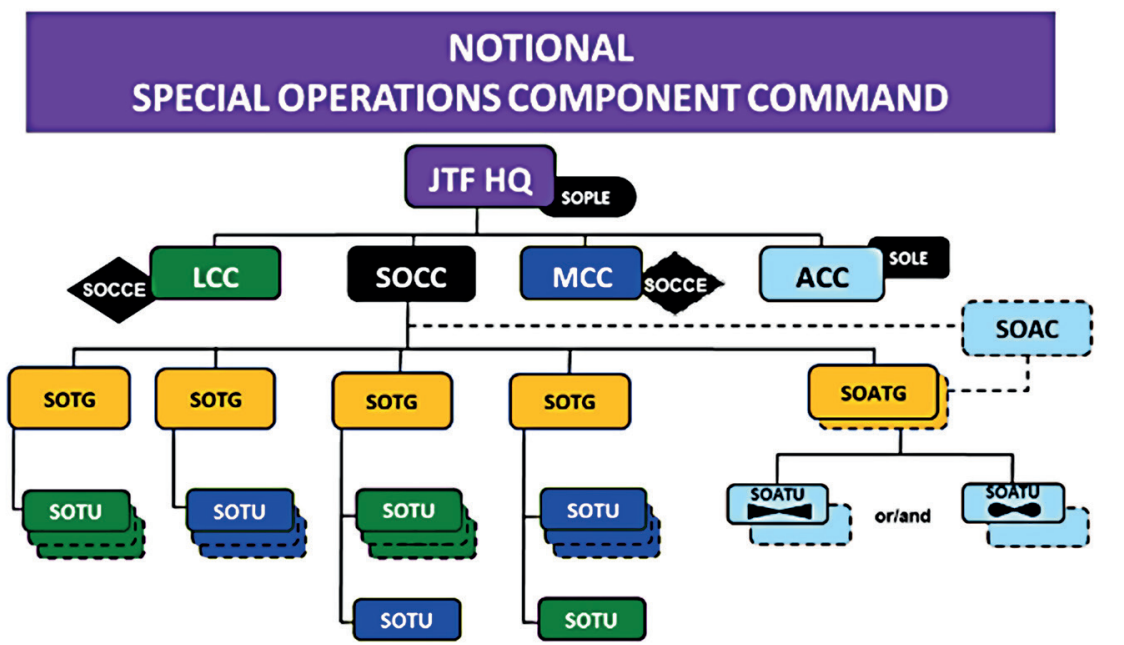

\begin{tabular}{|c|c|}
\hline JTF HQ - Joint Task Force Headquarters & SOLE - Special Operations Liaison Element \\
\hline ACC - Air Component Command & SOATG - Special Operations Air Task Group \\
\hline LCC - Land Component Command & SOATU - Special Operations Air Task Unit \\
\hline MCC - Maritime Component Command & \multirow{2}{*}{$\begin{array}{l}\text { SOTG - Special Operations Task Group: The abbreviation } \\
\text { SOTG is used here generically and can rofer to either a special } \\
\text { operatlons land task group (SOLTG) or to a speclal operations } \\
\text { maritime task group (SOMTG). }\end{array}$} \\
\hline socc - Special Operations Component Command & \\
\hline SOAC - Special Operations Air Command & \multirow{2}{*}{$\begin{array}{l}\text { SOTU - Special Operations Task Unit: The abbreviation SOTU } \\
\text { is used here generleally and can refer to elther a speclal } \\
\text { operations land task unit (SOLTU - depicted with green colour) } \\
\text { or to a special operations maritime task unit (SOMTU - depicted } \\
\text { with blue colour). }\end{array}$} \\
\hline SOPLE - Special Operations Planning and Llaison Element & \\
\hline SOCCE - Special Operations Command and Control Element & ........ formed when required \\
\hline \multicolumn{2}{|c|}{$\begin{array}{c}\text { The full Ilsting of requislte capabilitles that NATO requires from SOF is dellneated In B/-SC Agreed Capablitty Codes } \\
\text { and Capability Statements. }\end{array}$} \\
\hline
\end{tabular}

Figure 1.

Notional SOCC organisation [5: 15]

A SOCC is comprised of a combination of command and liaison elements, and force elements. Other troop-contributing nation may provide special operations land task groups, special operations air task units (SOATUs), or special operations air task groups (SOATGs) to the SOCC [5: 13-14]. 
SOCC could be an additional operation capability in the theatre. The addition of an operational command capability in the mission includes an operational command and control role through provision of the "core", which is an advanced party of 70-150 personnel, for an organic, rapidly deployable Special Operations Component Command when directed by the SACEUR. The NATO Special Operations Headquarters (NSHQ) does not currently have the ability to provide NATO with a rapidly deployable SOCC, which would include robust operational command, control, communication, computers, and intelligence (C4I) capabilities, equipped with organic special operations forces (SOF) enablers. Possessing a rapidly deployable SOCC Core would be a sound step toward establishing and ensuring interoperability among allied SOF units and commands, and enhance the employment of NATO Special Operations Forces [6: 23].

Since NSHQ does not have the ability to provide SOCC, consequently does not currently have the ability to provide SOF unique logistic support for a SOCC.

\section{SOCC Examples at the Margins of Publication}

NATO defence ministers of Belgium, Denmark, and the Netherlands have signed a memorandum of understanding (MOU) for the formation of a Composite Special Operations Component Command (C-SOCC). Once operational, the C-SOCC Special Forces Command will participate in the NATO Response Force. The three-national command will also be responsible for supporting NATO operations, in addition to other multinational missions. In 2017, defence ministers of the three nations launched the preparatory work and signed a Letter of Intent (Lol) to establish the C-SOCC. The special forces command is stated to reach initial operational capability (IOC) next year and is expected to be fully operational in 2021. NSHQ is currently responsible for providing advice and support for the creation of the C-SOCC, ensuring that the command is developed in line with NATO doctrine and standards. Belgium, Denmark and the Netherlands offer a quickly deployable NATO headquarters for carrying out and managing special operations. For the first time, the three countries have joined forces to jointly deliver a special forces headquarters to the alliance [11].

The Special Operations Joint Task Force - Afghanistan (SOJTF-A) conducts Special Operations activities with in the Coalition Joint Operations Area - Afghanistan (CJOA-A), in order to enable the International Security Assistance Force (ISAF), the Afghan National Security Force (ANSF), and the Government of the Islamic Republic of Afghanistan (GIRoA) to provide the Afghan people a secure and stable environment and to prevent insurgent activities from threatening the authority and sovereignty of GIRoA. SOJTF-A was formed in the summer of 2012. The objective of the new command was to bring all U.S. special operations forces in Afghanistan under a more unified command structure. The commander of SOJTF-A was also designated as the commander of the NATO Special Operations Component Command - Afghanistan [10]. 
Within the framework of an exercise (Black Swan 2017) ${ }^{3} 20^{\text {th }}$ Special Forces Group (Airborne) worked with SOF from Hungary, Bulgaria, Romania, Slovenia, Slovakia, Croatia, Former Yugoslav Republic of Macedonia; establishing a Hungarian-led Special Operations Component Command conducting an exercise across Hungary, Romania and Bulgaria [7].

This chapter confirmed the statement mentioned above, that the small NATO countries and partner small countries had focused on developing Special Operations Forces (SOF) capabilities to contribute to NATO.

\section{SOF Peculiar Logistic Support}

Support for SOF is tailored to the situation and mission with flexibility to withstand dynamic operational environments. Support arrangements often cross Service lines to utilise unique capabilities and sustain independent and low-visibility operations in austere and remote areas. SOF must be able to exploit information derived from the full range of intelligence (i.e. multinational, national, theatre and tactical), and often directly from ISR systems [4: IV-1].

Logistic support of SOF units is the responsibility of their parent service, except where otherwise agreed or directed. Services support SOF units whether the SOF unit is assigned to the service component, the theatre special operations command (TSOC), joint force special operations component commander (JFSOCC), or a joint special operations task force (JSOTF). SOF Service-common logistic support includes equipment, material and supplies. These include standard military items, base operating support, and the supplies and services provided by a Service to support and sustain its own forces, including those forces assigned to the CCMDs. Items and services defined as Service-common by one Service are not necessarily Service common for all other Services [4: IV-5].

In addition to commonly used military items, SOF uses special equipment as well. Consequently, SOF may need individual support, if it is impractical for conventional logistics. Further chapters of this publication focus on determining SOF unique logistic support. The main questions are the following:

- Why does SOF or SOCC need SOF specific logistic support?

- What does SOF specific logistic support stand for?

First of all, we must talk about some limitations concerning SOF. SOF has some operational and logistical restrictions, as well. Special operations are generally limited in scope by the size of the SOF unit. Improper employment of SOF runs the risk of rapidly depleting capacity. SOF cannot be quickly reconstituted or rapidly expanded, because of the lengthy process required to recruit, train and educate them. SOF are not a substitute for conventional forces (CF). In order to preserve SOF capabilities, SOF should not be employed to conduct operations where CF could be used to

Black Swan was one of a series of U.S. and European-led exercises under the umbrella of U.S. European Command's Saber Guardian, designed to enhance joint operational capability with allied and partner nations. 
achieve the same objectives. The most important statements concerning research are the following: The most special operations missions require CF logistic support. SOF are not structured with robust sustainment capabilities, therefore, SOF must frequently rely on external support for sustained operations. Limited SOF logistic capacity frequently requires support from CF supplemented by host-nation support (HNS) and/or operational contract support [4: I-6, I-7].

SOF and CF's level of commitment throughout the joint operations are different, see below.



Figure 2 .

SOF and CF's level of commitment throughout the joint operations [8: 4]

The joint operational phases are the following: shape, deter, seize initiative, dominate, stabilise, enable civil authority and back to shape. Because special operations can provide a discreet, precise, politically astute and scalable capability, they are frequently used in diplomatically sensitive missions. In these diplomatically sensitive environments, Army special operations forces create effects of a magnitude disproportionate to their small footprint [8: 4]. 
The "abyss" between the red and blue line emphasises the difference between SOF and CF's level of commitment. Although SOF operates a full spectrum of operations, still effective logistic support simply does not exist in the early phase of joint operations. After a short analysis, it can be said: neither "full" CF in theatre, nor effective conventional logistics for SOF. Consequently, SOF need "additional" logistic support in addition to conventional logistic support. This added "value" can be called: Special Operations Forces peculiar logistic support.

\section{Fundamentals of the SOCC Logistic Support System}

The nature of special operations often requires independent forces operating in austere, remote locations without a robust logistics infrastructure. SOF logistics are expeditionary in nature and are tailored and structured for rapid deployment into austere environments. To maintain the necessary flexibility and independence in such circumstances, a SOCC logistic support element is necessary to bridge the gap to conventional logistic support. As discussed in the previous chapter, SOF require both standard and SOF-peculiar (non-standard) material and logistics. Logistic support (and CSS) for special operations is characterised by a multifaceted environment that includes deployment, initial entry, build-up and integration, and redeployment. The challenge for SOCC planners is the coordination required to address both operational and national considerations. Special operations elements (SOTGs and SOATGs) are expected to operate in any environment without support or replenishment for a minimum of 30 days $^{4}$ [5: 163].

The SOCC J4's responsibilities encompass the areas of supply and materiel services. According to the SOCC Manual, these areas are the following: logistic information management; equipment maintenance and repair; movement and transportation; reception, staging, and onward movement/integration (RSOM/RSOI); petroleum logistics; explosive ordnance disposal; medical logistics; infrastructure engineering for logistics; medical support; contracting; and host-nation support (HNS), as well as the related functions of CIMIC, NATO standardisation, interoperability, and environmental protection. ${ }^{5}$

Supply: Each SOF element has organic support capabilities to sustain or provide support to their units. Resupply of deployed SOF elements in remote or denied areas is planned and executed as an operational task and may require the use of non-standard transportation or SOF aviation assets. The Joint Logistic Support Group (JLSG) and National Support Elements (NSE) can assist the SOCC J4 in fulfilling logistic requirements. Agreements concerning the common user item list can reduce the duplication of effort and greatly assist SOF logistic support. When a TCN component or agency is designated as the CUIL lead to provide selected common items, such as food, water, or fuel, they support multiple deployed elements [5: 163-164].

This includes all classes of supply.

J4 responsibilities may be different in small NATO member countries.

Hadmérnök • 14. évfolyam (2019) 4. szám 
Maintenance: Equipment unique to a troop-contributing nation (TCN) remains the maintenance responsibility of the TCN deployed element. Special operations elements may have the capability to perform limited maintenance but often require deployment of specialty personnel or support units to maintain and repair equipment that is unique to special operations. When practical, maintenance facilities for cross-TCN use and retrograde procedures for returning, repairable items should be established. Multinational use of salvage assets should be emphasised. Maintenance priorities normally emphasise return of mission-essential weapon systems to combat readiness [5: 164].

Fuel: While most fuelling operations are included in base support, during expeditionary operations, the SOCC and deployed forces may require fuel support from organic resources until NATO establishes an appropriate fuel resupply infrastructure. Fuel support for special operations aircraft includes testing and certification of $\mathrm{HN}$ fuel supplies using NATO standards of acceptability and supervising local military and civilian refuelling personnel to ensure safe refuelling operations with NATO combat aircraft. The SOAC J4 is responsible for ensuring the SOATGs to provide sufficient personnel trained and certified to accurately assess and verify the quality of the HN fuel, HN storage procedures, and planned defences against possible contamination and attack [5: 164].

Transportation: Given the nature of most special operations, time constraints, planning considerations, or special mission requirements may place unique demands on common-user transportation assets. Generally, strategic movement assets support SOF in the deployment, resupply, and redeployment phases of the operation. SOF organic airlift assets normally provide SOF with intra-theatre lift support (insertion, extraction and resupply). When SOF operations exceed the organic SOF lift capability, then common-user transportation assets should be considered. The SOCC J4 is responsible for coordinating all non-operational associated transportation. This is usually done through a joint movement coordination centre or a similar organisation established for movement control. The SOCC and subordinate units are responsible for the coordination of administrative transportation at their respective levels; however, transportation to and from SOF operational areas, especially resupply or casualty evacuation (CASEVAC) in support of deployed operational elements, is often conducted as tactical operations under J3 direction [5: 164].

Medical Support: Normally, an LN provides medical support to NATO forces in theatre. The SOCC medical staff coordinates preventive medicine practices to mitigate any environmental factors that may impact the SOTGs/SOATGs. The medical staff provide detailed medical planning and medical intelligence to COM SOCC prior to deployment and recommend organisational and personnel actions to counter potential threats to personnel health. The medical staff also plan for and coordinate the MEDEVAC procedures. The SOCC may maintain a Role 2 medical facility and a special operations surgical team [5: 164]. 


\section{SOCC Logistic Support Concept for Small States}

The previous chapter highlighted some details that are relevant to the publication. After the presented SOCC logistic fundamentals, this chapter presents a recommended SOCC logistic concept for small NATO members and NATO partner countries.

In the small NATO members and NATO partner countries, SOF totally depend on their own national logistics. These logistic systems are based on the supply chain approach. Occasionally, due to their special missions, conventional logistics cannot provide effective support for SOF. Because of the above mentioned facts, SOF peculiar logistic support requires a kind of comprehensive approach. Some non-traditional logistic "organisation" should be founded in order to counteract the shortcomings mentioned above. These units (subunits) should be operational, until conventional logistics is able to support SOF. This idea is illustrated in the next figure, see below.

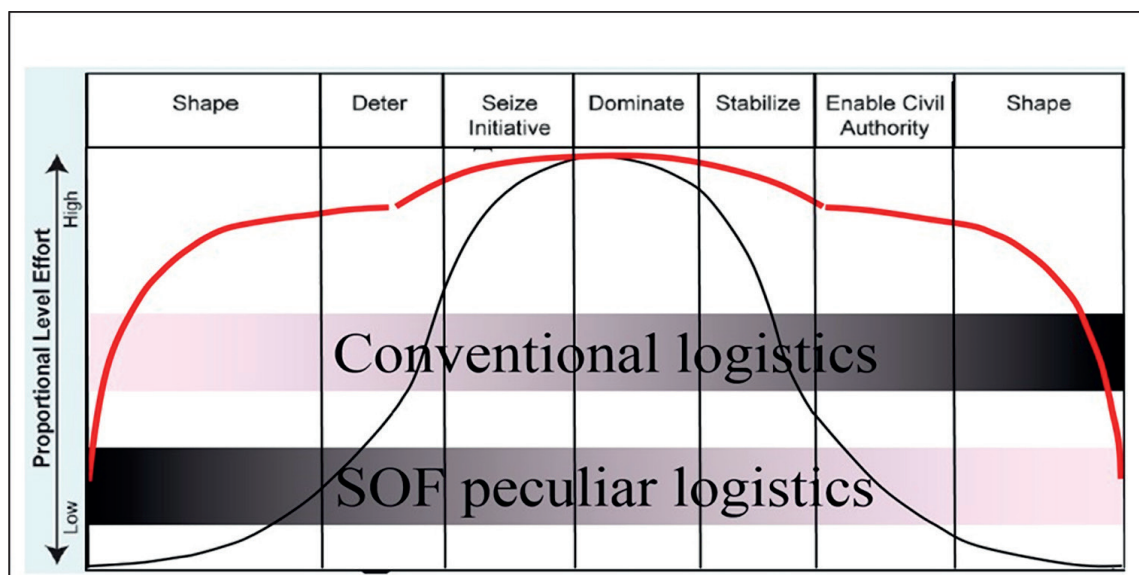

Note: The darker gradient depicts the logistic forces' level of commitment throughout the joint operational phases.

Legend:

Proportionality of operational focus/commitment of forces:

Special Operations Forces:

Conventional forces:

Figure 3.

SOCC logistic support concept [Compiled by the author.]

After a short analysis, the followings can be stated:

- The difference between SOF and CF's level of commitment is significant

- Special Operations Forces operate a full spectrum of operations in the early phases of the joint operation

- No significant/effective conventional logistic forces in the field in the early phases of the joint operation 
Consequently:

- Conventional logistics cannot support SOF effectively

- Conventional logistics must be supplemented by SOF peculiar elements

- Duplicate of logistic capability should be avoided in order to mitigate logistical footprint

\section{The Concept in Practice - Summary}

I think the concept can be realised in two ways. The first option is a SOF framework nation's own logistics, the other is a SOF peculiar multinational integrated logistic unit. The first option includes a fast deployable, modular SOF peculiar combat service and logistic support unit, according to the SOCC requirement. ${ }^{6}$ The second option is multinational logistics. I will present the second option in this chapter.

According to the meetings of NATO Defence Ministers in Brussels, 2017, SOCC can be based on an international agreement [9]. Consequently, SOCC logistics could be based on international logistics. In this case, the following factors influence logistics:

- Nature of SOTGs (SOATG, SOTUs, etc.)

- Special Operations core activities and missions

- Duration of Special Operations missions

- Host nation support (HNS) capabilities

- Base logistic support

- National logistics capabilities

- National caveats and limitations

In this case CSS must be able to support SOCC and SOTUs according to the above mentioned requirements. In this case one nation (SOF framework nation) provides basic capabilities, and the nucleus of logistics. ${ }^{7}$ Partner nations provide additional abilities. The criteria mentioned above meet the requirement of NATO MILU requirement, supplemented with SOF requirements.

Advantages:

- based on existing national logistic capabilities

- can be organised as a multinational logistic unit

Disadvantages:

- MILU has been characterised to support low intensity operations

- organisation and capabilities are not flexible

- force generation cannot be fast because of the rules of international force generation procedure

- this methodology is not mentioned by the SOCC manual as a possibility of SOCC logistics

See the above mentioned chapters: SOCC Requirement, Fundamentals of the SOCC Logistic Support System. Key leaders, key staff personnel, command and control. 


\section{References}

[1] NATO Special Operations Headquarters. Special Operations Forces. NATO Special Operations Headquarters, Mons, Belgium, 2015. [Online]. Available: www.nato. int/cps/en/natohq/topics_105950.htm\#top [Accessed Oct. 2, 2019].

[2] M. Saiti, Small Countries'Special Forces Contribution to the NATO Response Force. Fort Leavenworth, Kansas, U.S. Army Command and General Staff College, 2014.

[3] JP 3-05. Special Operations. Tampa, Florida, United States Special Operations Command, 2011.

[4] JP 3-05. Special Operations. Tampa, Florida, United States Special Operations Command, 2014.

[5] SOCC Manual. Mons, Belgium, NATO Special Operations Headquarters, 2014.

[6] J. Krott, F. Morales, and W. Livingston, Development of a rapidly deployable Special Operations Component Command (SOCC) core concept for the North Atlantic Treaty Organization (NATO) Special Operations Headquarters (NSHQ). Monterey, California, Naval Postgraduate School, 2011.

[7] J. Friberg, Exercise Black Swan 2017 - U.S. SOF Work with NATO SOF. SOF NEWS. [Online]. Available: https://sof.news/exercises/black-swan-2017/ [Accessed Sept. 5, 2018].

[8] ADP 3-05. Special Operations. Washington, D.C., Headquarters, Department of the Army, 2018.

[9] "Allies take steps to create multinational Special Forces command," NATO Special Operations Headquarters. [Online]. Available: www.nato.int/cps/en/natohq/ news_141441.htm [Accessed Sept. 7, 2018].

[10] "NSOCC-A. Special Operations Joint Task Force - Afghanistan (SOJTF-A)". [Online]. Available: www.globalsecurity.org/military/agency/dod/sojtf-a.htm [Accessed Sept. 5, 2018].

[11] "Belgium, Denmark and Netherlands sign MoU to form C-SOCC," Army Technology, June 12, 2018. [Online]. Available: www.army-technology.com/news/ belgium-denmark-netherlands-sign-mou-form-c-socc/ [Accessed Sept. 5, 2018]. 